\title{
Development of a Creative Gymnastics Model to Improve Basic Locomotor Movements for Students in Elementary School
}

\author{
Palmizal A..$^{1, *}$, Dian Pujianto ${ }^{2}$, Nurkadri $^{3}$, Anak Agung Ngurah Putra Laksana ${ }^{4}$ \\ ${ }^{1}$ Faculty of Teacher Training and Education, Universitas Jambi, Jambi, 36361, Indonesia \\ ${ }^{2}$ Faculty of Teacher Training and Education, Universitas Bengkulu, Bengkulu, 38371, Indonesia \\ ${ }^{3}$ Faculty of Sport Science, Universitas Negeri Medan, Medan, 20221, Indonesia \\ ${ }^{4}$ Faculty of Teacher Training and Education, Universitas Mahadewa, Denpasar, 80235, Indonesia
}

Received September 22, 2020; Revised November 27, 2020; Accepted December 22, 2020

\section{Cite This Paper in the following Citation Styles}

(a): [1] Palmizal A., Dian Pujianto, Nurkadri, Anak Agung Ngurah Putra Laksana, "Development of a Creative Gymnastics Model to Improve Basic Locomotor Movements for Students in Elementary School, International Journal of Human Movement and Sports Sciences, Vol. 8, No. 6A, pp. 78-84, 2020. DOI: 10.13189/saj.2020.080714.

(b): Palmizal A., Dian Pujianto, Nurkadri, Anak Agung Ngurah Putra Laksana (2020). Development of a Creative Gymnastics Model to Improve Basic Locomotor Movements for Students in Elementary School. International Journal of Human Movement and Sports Sciences, 8(6A), 78-84. DOI: 10.13189/saj.2020.080714.

Copyright $\mathrm{C} 2020$ by authors, all rights reserved. Authors agree that this article remains permanently open access under the terms of the Creative Commons Attribution License 4.0 International License

\begin{abstract}
This study aims to produce a creative exercise learning model for the basic locomotor movements of elementary school students. This study uses the Research \& Development (R\&D) development research method from Borg and Gall in Sugiyono. The small group test consisted of 10 students at the State Elementary School 40 / XI Talang Duku, Muaro Jambi Regency, the item model, in the large group trial of 18 students with 28 model items. The 10 students' effectiveness test used the locomotor test with the one-group pretest-posttest design by obtaining the effectiveness test value with an average pre-test result of 34.30 and an average post-test result of 69.90 with sig. 0.00 then the data is declared homogeneous. Therefore, the data read is equal variances assumed, so the t-count is greater than the $t$-table $(20.463>2.26216)$ with a significant expectation of $1 \%$, df 9 and sig. (2-tailed) $=0.000<0.05$ with an explanation of the application of the creative exercise learning model for basic locomotor movements of elementary school students effectively. Based on the results obtained, it can be concluded that: (1) With this creative exercise learning model, students can learn more effectively and efficiently, (2) with this creative exercise learning model, an increase is shown in the pre-test and post-test results. There is a significant difference.
\end{abstract}

Keywords Learning, Creative Gymnastics, Locomotor

\section{Introduction}

Education plays a very important role in creating the quality of human beings. This is because that education is a planned effort to create an atmosphere of learning and the learning process so that students actively develop their potential to have religious-spiritual strength, self-control, personality, intelligence, noble character, and skills needed for himself, society, the nation, and the state [1].

Learning is a relatively permanent change in behavior or potential behavior as a result of strengthened experience or practice. Learning is also a form due to the interaction between stimulus and response. "Learning is an activity or a process to acquire knowledge, improve skills, improve behavior, attitudes, and strengthen personality"[2]. These changes occur as a result of an experience or practice, in contrast to changes immediately due to reflexes or instinctive behavior.

Learning basic locomotor movements in elementary schools still shows some problems that can be used as a basis for improvement. For example, the basic locomotor movement of walking (a) Simultaneously swing between one side of the arm and leg (the arm should move freely in 
the opposite direction of the leg ), (b) Failure to bend the ankles, knees (stiffness), or hips, causing a bouncing or stiff look, (c) incorrect posture indicated by the forward pulling of the head and torso, rounded shoulders or bending while the hips pushed forward (head and body should be upright), (d) shifting the heel on the floor (pushing up or forward starting from the toes).

Physical education is one of the subjects that must be carried out in school, namely as a main subject that must be followed by all students. This subject has uniqueness compared to other subjects, namely the use of physical activity as a means / media in educating students. "Physical education is education through physical activity by participating in physical activities, and students can master skills and knowledge, develop aesthetic appreciation, develop generic skills and positive attitude values, and improve physical conditions to achieve physical education goals"[3]. Gross Motor Skills Development plays a very important role in the field of Sports Studies. By constantly and scientifically monitoring their gross motor skills in the sports and recreational activities which they are involved in, such as martial arts, it can assure and guide the development of young children motor development. Also, it is important to find out which martial arts would develop more gross motor skills of these children [4].

Basic motion is a repetitive motion that is carried out continuously from the habit and from the experience of their environment. Basic motion development is a process to obtain motion that is constantly developing based on: (1) the process of developing nerves and muscles which is also influenced by heredity, (2) a result of previous experience of motion, (3) current experience of motion. Locomotor movement is a movement characterized by a movement of places, such as walking, running, jumping, and rolling [5]. Locomotor movements are the basis for the development of coordination of movements involving the gross-muscles, muscle growth, endurance and stamina. This movement usually makes children feel happy doing it.

Basic locomotor motion is the basis for various skills that really need guidance, learning and development so that children can carry it out properly. Some of the basic locomotor motion develops as a result of several stages. The process of forming motion does not occur automatically, but is an accumulation and process of learning and practicing, namely by understanding the movements and making repetitive movements accompanied by awareness of the movements being carried out [6]. The purpose of doing the repetition of the basic movements of walking, running and jumping is to improve the basic movement skills that are widely practiced in everyday life.

Rhythmic gymnastics is one of the choices of rhythmic activity in the basic competencies of learning Physical Education and Health. Its implementation must refer to educational goals, including developing self-skills in psychomotor development and maintenance of physical fitness and a healthy lifestyle through various rhythmic activities at school. Besides, it is also stated that the purpose of Physical Education and Health is to understand the concept of physical activity and exercise in a clean environment as information to achieve perfect physical growth, healthy lifestyle and fitness, skilled, and have a positive attitude.

Gymnastics can educate students to love health. In addition, gymnastics can also be done to relax (peace of mind), for flexibility, freshness, and body fitness which are very important for one's survival. Gymnastics education is unique from other content because it plays a role in sports and daily life by helping people learn to manage their bodies efficiently and safely. Gymnastics is a competitive sport that involves a series of maneuvers that require strength, flexibility, balance and a high level of motor control [7], consisting of a variety of styles including artistic, rhythm-mic, trampoline and tumbling. Gymnastics is carried out on the basis of the principle of cardio rephrased exercise according to Batteneli's opinion, and this exercise is done two to three times a week with an intensity of $60-90 \%$ of the maximum pulse. "Gymnastics is a sport that is cheap, fun, mass, interesting and useful.

According to Jhon and Mery, gymnastics has a lot of influence for individuals when they come to exercise with good attitude and respect. "Gymnastics can be fun, exciting, giving a lot of charm, and you will feel confident in yourself and proud of the achievements you can achieve"[8]. Gymnastics will also train walking, running, jumping, strength, balance, rhythm, and flexibility.

One research method that is relevant and can always be used is Research and Development (R\&D). Thus development research can be concluded as research that produces a products that have been analyzed beforehand the level of effectiveness in learning, and have been designed, evaluated and revised with the results of the development of the model [9]. In this case, what will be developed is rhythmic exercise with a creative gymnastics model to improve the basic locomotor movements of elementary school children. Therefore this study aims to develop a creative exercise model to improve the basic locomotor movements of students by making exercises that are interesting and easy to follow by students, using rhythms or children's songs that they often hear or sing so that it makes them happier and more.

The conceptual model is an analytical model, which states the components of the product, analyzes the components in detail and shows the relationships between the components to be developed. Theoretical model is a model that draws a frame of mind based on relevant theories and is supported by empirical data. Some opinions about the model that have been explained can be interpreted that the model is a picture that aims to clarify something [10]. The model intended in this research and 
development is a pattern description which includes analysis, development, material creation, and evaluation to achieve the learning objectives of rhythmic gymnastics for basic locomotor movements, because learning requires a variety of learning models that can help the process of achieving maximum learning.

\section{Materials and Methods}

\subsection{Type of Research}

Research on the development of rhythmic gymnastics with a creative gymnastics model for basic locomotor movements of elementary school children uses the research and development model of R\&D (Research and
Development) from Borg and Gall [11].

\subsection{Characteristics of the Model Developed}

Planning and design are made to provide clear instructions and guidance in conducting research later in learning, planning, and compiling learning models are factors that determine the success of a program. In this connection, the rhythmic gymnastics learning model that will be arranged in the form of modification and creativity in the form of rhythmic gymnastics learning to increase locomotor basic movement will be made and developed in the form of several new learning models and make children happier about learning creative gymnastics models. The characteristics of the learning model being developed are as follows figure 2.[11]

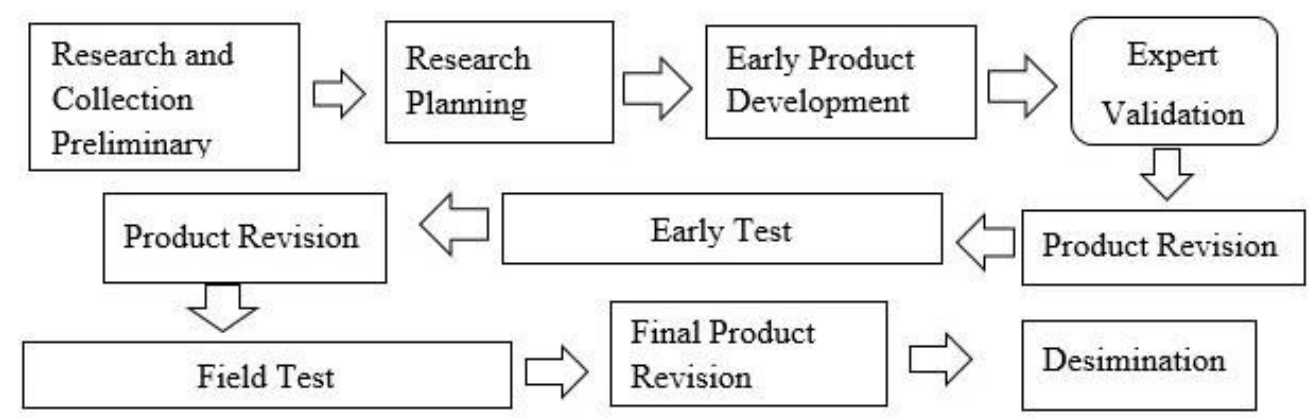

Figure 1. The Borg \& Gall Development Model

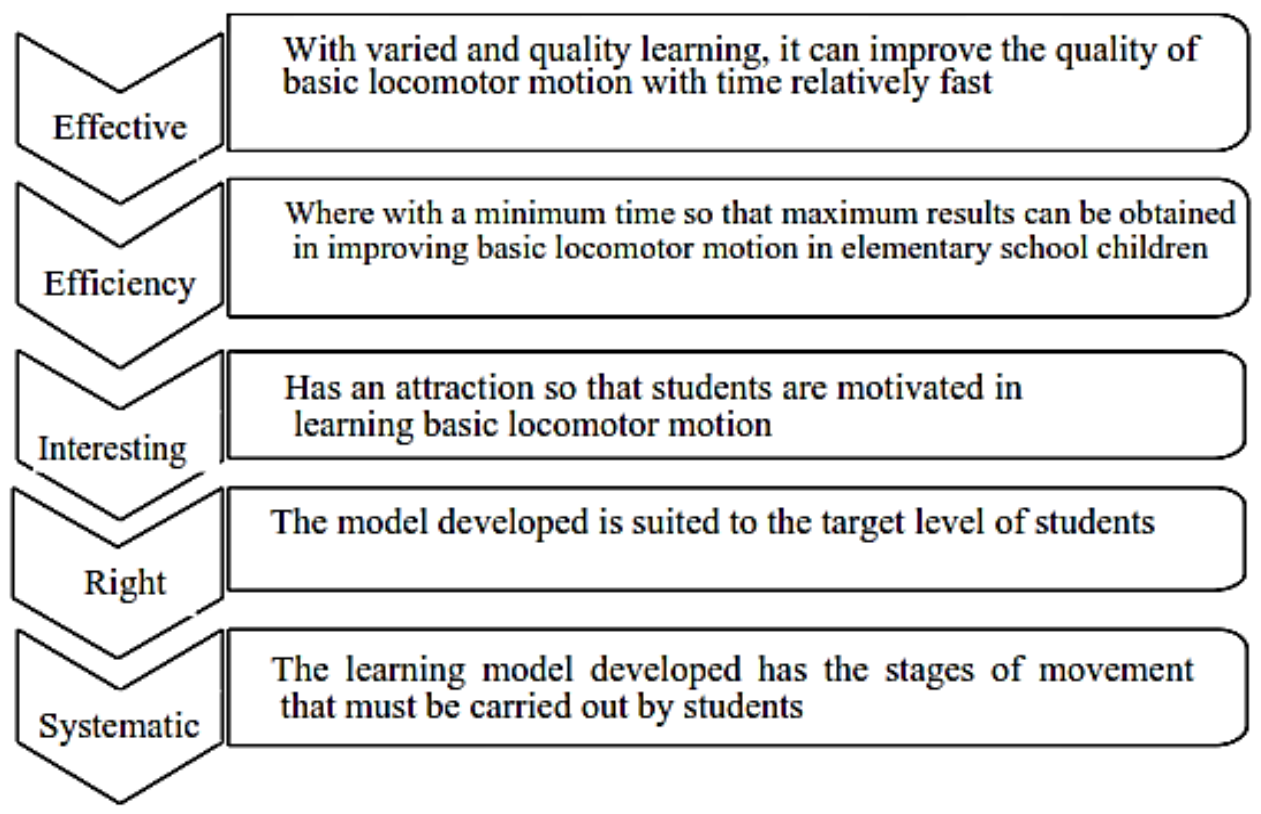

Figure 2. Characteristics of Developed Model 


\subsection{Model Development Steps}

The steps taken in the research and development of this model go through the following stages:

1) The first evaluation stage is carried out at the design stage of the model form by experts, and the initial evaluation is the first assessment of the experts to (a) determine whether the model is following the characteristics required in the rhythmic gymnastics model with creative gymnastics for basic locomotor movements for elementary school students, (b) whether the learning model developed is suitable for elementary school students' locomotor movement before it is tested, (c) whether the creative gymnastics makes it easier for students

2) The second stage of evaluation is carried out at the small group trial stage. In this evaluation, through the results of the response to the learning model in the trial phase, it was carried out by elementary school students, among others. (a) the learning model is easy to learn, (b) the learning model is attractive, (c) the learning model is very effective and others. Results of primary school students' responses based on the learning model development model that has been implemented are evaluations of the improvement of learning model products in elementary school students before the learning model is field-tested in heterogeneous groups of abilities and a larger number of students.

3) The final evaluation stage is carried out at the large group field test stage and the skill level is heterogeneous. The results of student responses to the learning model are the same as the questions in the previous evaluation stage which will later be a revision of the improvement of the results of rhythmic gymnastics models with creative gymnastics for elementary school students' locomotor movements and implemented. Research and development of this model uses the development steps of the Borg and Gall [11]. The steps for developing the model include the following:

Table 1. Description and Subject

\begin{tabular}{|c|c|cc|}
\hline Stages & Step & \multicolumn{1}{c|}{ Activity } \\
\hline $\begin{array}{c}\text { Pre } \\
\text { Development }\end{array}$ & 1 & $\begin{array}{l}\bullet \\
\text { - }\end{array}$ & $\begin{array}{l}\text { Initial data collection } \\
\text { Preparation of research proposals } \\
\text { Needs analysis }\end{array}$ \\
\cline { 2 - 4 } Development & 3 & $\begin{array}{l}\text { Designing the model to be applied } \\
\text { Validation by experts } \\
\text { Revise the results of expert } \\
\text { evaluations }\end{array}$ \\
\hline Application & 4 & $\begin{array}{l}\text { Small group trials. } \\
\text { 3erformed with 10 people sample }\end{array}$ \\
\cline { 2 - 4 } & 5 & $\begin{array}{l}\text { Revise the test results small group } \\
\text { limited scale of 10 students } \\
\text { Product revisions from test results } \\
\text { try }\end{array}$ \\
\hline
\end{tabular}

\subsection{Data Collection}

The instrument used in the development of creative exercise model learning for elementary school students' locomotor movements was a questionnaire and a locomotor basic movement skill test. The questionnaire was used for needs analysis and expert evaluation (in phase I trials and phase II trials). The needs analysis questionnaire in this study was used to obtain teacher opinion data on the learning models that have been or are being used and what kind of learning model is desired.

\subsection{Data Analysis}

There are two data analysis techniques used, namely: qualitative analysis and quantitative analysis. If the data obtained is descriptive that cannot be converted into numbers, then the data analysis uses qualitative analysis. While the data collected can be classified or converted into numbers, quantitative data analysis is suitable. The data analysis technique used in this research is qualitative analysis techniques and quantitative analysis techniques. Qualitative analysis techniques are used to analyze data obtained from experts in the form of suggestions and input that cannot be converted into numbers, while quantitative analysis techniques are used to manage data obtained from the results of small group trials and large group field trials and effectiveness testing model.

The formula for processing data per trial subject.

$\mathrm{P}=\mathrm{Xi} 100 \%$

Information:

$\mathrm{P}=$ percentage of evaluation results of trial subjects

$\mathrm{X}=$ The number of score answers by the test subjects

$\mathrm{Xi}=$ The maximum number of answers in the assessment aspect by the test subject

$100 \%=$ Constants

\section{Results and Discussion}

\subsection{Model Development Results}

The results of the creative gymnastics learning model for elementary school students' locomotor movement are written in the form of a script which is presented in various forms of locomotor basic movement learning models.

\subsection{Needs Analysis Results}

After conducting interviews and observations or observations of elementary schools, there are two general objectives to be revealed in the preliminary study or needs analysis, namely, a) How important is the rhythmic gymnastics learning model through creative exercise for basic locomotor movements of elementary school students, especially the lower classes. b). What constraints and 
support are found in developing a gymnastic learning model for basic locomotor movements of elementary school students. After carrying out the data collection stage and drafting a creative exercise learning model for elementary school students' locomotor movement, the next step is to do an expert test where the goal to be achieved is to get the feasibility or validity of the model made by direct assessment of the experts. The author validates with 2 experts in assessing the feasibility of creative gymnastics learning models for elementary school students' locomotor movements, 1 person as a material expert, and 1 person as a media expert. The following is a model validation process from experts.

\subsection{Expert Validation}

Based on expert validation from small group trials conducted by the author that there are 28 worthy of the 34 forms of learning models that have been applied, based on expert tests conducted on learning models of creative gymnastics models for basic locomotor movements of elementary school students, the following conclusions can be drawn : (1) Based on the expert test, it can be concluded that the item models 18, 19, 20, 30, 31 and 33 are learning models that are not feasible to be given to students in the primary school category (2) For learning model items 18, 19, 20,30, 31 and 33, it is still difficult for students to do this in the primary school category. (3) Implementation instructions must be made clear so that they are easy to understand (4) Based on expert testing conducted from 34 items of learning models, 28 items of learning models will be tested at the next stage.

Based on the small group trials, the following conclusions can be drawn: a). All items of learning models can be done and applied but must be adjusted from easy to difficult levels so that elementary school students' basic locomotor mobility can be improved. b). When doing the creative exercise learning model, it is often not serious, the teacher must provide direction so that students can carry out learning correctly according to the teacher's direction so that students will get the expected results.

\subsection{Model Eligibility}

The conclusions from the expert tests carried out are summarized in the following table: Based on the expert tests conducted, it can be concluded that this creative exercise learning model is feasible and can be used in improving the basic locomotor movement skills of elementary school students: a). The movement model given must be following the level of difficulty for students in the category of elementary school students. b). The facilities or music provided must also be adapted to the category of elementary school students by using children's song music. c). Implementation instructions must be made clear so that they are easy to understand. d). Each given learning model must have clear objectives so that it contributes to basic locomotor movement skills.

\subsection{Model Effectiveness}

\subsubsection{First Stage Results / Small Group Trials}

The learning model of creative gymnastics for basic locomotor movements of elementary school students that the author made after being evaluated by an expert, then underwent a stage I revision. The data obtained were used as a basis for revision in the first stage, then the second stage trial, getting the results of the revision of 28 model items which are composed of easy, medium, and difficult ones.

The next step after the model underwent a revision from the expert, and it was continued by testing the product in a large group using 10 students as research subjects because they were still in a new normal state taken from Talang Duku public elementary school students of 40 / IX, especially the low class.

Table 2. Paired Samples Test

\begin{tabular}{|c|c|c|c|c|}
\hline & Mean & $\mathrm{N}$ & Std. Deviation & $\begin{array}{c}\text { Std. } \\
\text { Error } \\
\text { mean }\end{array}$ \\
\hline Pair 1 & 34,30 & 10 & 3.743 & 1.184 \\
Pretest & 69,90 & 10 & 7.249 & 2.292 \\
\hline
\end{tabular}

Table 3. Correlation Test

\begin{tabular}{|c|c|c|c|}
\hline Pair 1 & $\mathrm{N}$ & Corelation & Sig \\
\hline $\begin{array}{c}\text { Pre test } \\
\text { \& Pos test }\end{array}$ & 10 & .669 & .035 \\
\hline
\end{tabular}

Table 4. Paired Differences Test

\begin{tabular}{|c|c|c|c|c|c|c|c|c|}
\hline \multirow{3}{*}{ Pair 1} & \multicolumn{5}{|c|}{ Paired Differences } & \multirow{3}{*}{$\mathbf{T}$} & \multirow{3}{*}{ df } & \multirow{3}{*}{$\begin{array}{c}\text { Sig. } \\
\text { (2-tailed) }\end{array}$} \\
\hline & \multirow{2}{*}{ Mean } & \multirow{2}{*}{$\begin{array}{c}\text { Std. } \\
\text { Deviation }\end{array}$} & \multirow{2}{*}{$\begin{array}{c}\text { Std. } \\
\text { Error } \\
\text { Mean }\end{array}$} & \multicolumn{2}{|c|}{$\begin{array}{l}95 \% \text { Confidence Interval } \\
\text { of the Difference }\end{array}$} & & & \\
\hline & & & & Lower & Upper & & & \\
\hline $\begin{array}{l}\text { Pos Test - } \\
\text { Pre Test }\end{array}$ & 35.60 & 5.502 & 1.740 & 31.664 & 39.536 & 20.463 & 9 & .000 \\
\hline
\end{tabular}




\subsection{Effectiveness Test of Experiment Group and Control Group}

Before carrying out research or providing model treatments, the authors first performed a preliminary test and a final test after the treatment was applied using a locomotor basic movement skill test instrument made and developed by the author and validated by an expert. The treatment of 28 items of the creative gymnastics learning model was divided into 10 meetings. The following is a table of treatment for 10 meetings. Due to the condition of COVID-19, the assessment data was only carried out by 10 students before and after being given a creative exercise learning model treatment for basic school students' locomotor movements and the results of the control group that were not given a creative exercise learning model or treatment as shown in the following table 5:

Table 5. Effectiveness Test Data Results

\begin{tabular}{|c|c|c|c|}
\hline \multirow{2}{*}{ No } & \multirow{2}{*}{ Subjek } & \multicolumn{2}{|c|}{ Effectiveness Test } \\
\cline { 3 - 4 } & & Pretest & Postest \\
\hline 1 & $\mathrm{X} 1$ & 32 & 74 \\
\hline 2 & $\mathrm{X} 2$ & 27 & 62 \\
\hline 3 & $\mathrm{X} 3$ & 34 & 69 \\
\hline 4 & $\mathrm{X} 4$ & 40 & 79 \\
\hline 5 & $\mathrm{X} 5$ & 37 & 70 \\
\hline 6 & $\mathrm{X} 6$ & 34 & 68 \\
\hline 7 & $\mathrm{X} 7$ & 31 & 65 \\
\hline 8 & $\mathrm{X} 8$ & 36 & 77 \\
\hline 9 & $\mathrm{X} 9$ & 34 & 57 \\
\hline 10 & $\mathrm{X} 10$ & 38 & 78 \\
\hline \multicolumn{2}{|c|}{ Average } & 34 & 70 \\
\hline \multicolumn{2}{|c|}{ Amount } & 343 & 699 \\
\hline
\end{tabular}

Based on the results of the output using SPSS 22, it can be seen that the value of the effectiveness test with an average pre-test result of 34.30 and an average post-test result of 69.90 means that from the average value above it can be concluded with the treatment model. learning the basic locomotor movement of creative gymnastics has increased significantly.

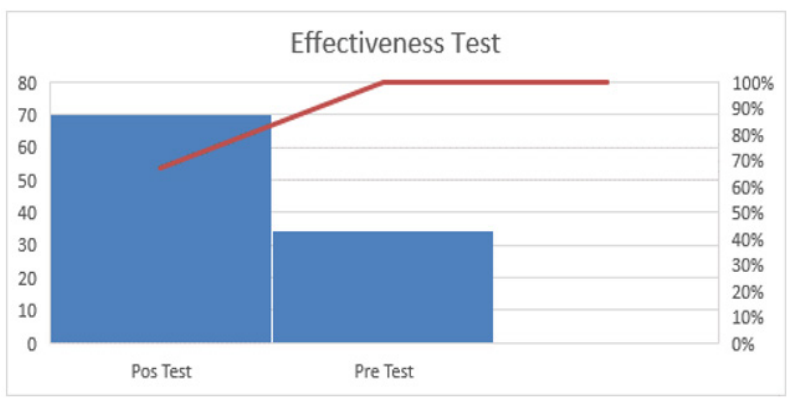

Figure 3. Histogram Effectiveness Test

\section{Discussion}

\subsection{Product Enhancements}

Based on the research process that has been carried out, creative gymnastics learning model is produced for the basic locomotor movements of elementary school students. This learning model is made so that students are more active in moving and excited, especially in basic locomotor movements of walking, running, and jumping. The foundation for creating or making this learning model based on previous learning models seems monotonous and less creative. Seeing the shortcomings and advantages of the products made, there are inputs that researchers will convey to achieve the improvement of this product, while the input is as follows: a). In this model, it is necessary to adjust the movements of students who use this creative exercise model. b). The characteristics and understanding of students in the primary school category require teachers to provide direct examples and practice for students to learn movements that are new and difficult to do.

\subsection{Product Discussion}

The creative gymnastics learning model created by this author is a product that aims to assist teachers in delivering and providing creative exercise learning material to students, improving basic movement skills, and as a reference for learning materials. This creative exercise learning model is made based on the level of students' needs, especially elementary school students, especially the lower classes. This product, after being reviewed regarding several weaknesses that need improvement, can be conveyed several advantages of this product, including a). Improve basic locomotor movement skills. b). Creative exercise models are more effective and efficient. c). Can help teachers in the learning process at school more interestingly and make students happy. d). As a reference for learning at school. e). This exercise model is done systematically from easy to difficult things. f). The models used are varied and the music or songs used are children's songs that they often sing so that it makes students interested and enthusiastic about carrying out the exercise.

\subsection{Product Limitations}

There are still some limitations that must be recognized and put forward as a consideration for the research achieved. The limitations include the following: a). This research field trial is limited due to the presence of COVID-19 so that the scope and sample are limited, and it would be better if it was carried out in a wider scope. b). The products used are far from perfect. c). The facilities and infrastructure used are still limited. d). The explanation and regulations in the creative exercise 
learning model are still far from perfect. e). There are psychological factors that are thought to have contributed to the uncontrolled research results, including interest, trust, and other psychological factors.

The application of cheerful gymnastics is able to improve fine motor skills in early childhood group B children 4-5 years old [12]. Another opinion stated that the RC one rhythm gymnastics learning model for the basic motion of elementary school children is declaredly effective in improving the basic motion of elementary school children [13]. Based on the results, it can be concluded that: (1) With this RC one rhythm gymnastics learning model, students can learn more effectively and efficiently, (2) by RCone rhythm gymnastics learning model, obtained improved shown in the final result. Physical education learning has problems in the learning process due to inadequate facilities and infrastructure that the school has so that students have difficulty in improving basic motion skills [14].

\section{Conclusions}

Based on the data obtained from the research results obtained data in small group trials of 10 students with a model that was applied as many as 34 items of locomotor basic movement learning models, then a revision of the model was carried out to gymnastics experts against the model that the researchers had applied to small group trials, from the revised results then into 28 model items, in a large group trial with a total of 18 students, after a large group trial the researcher revised the model that had been applied to the experts and found that 28 models of rhythmic gymnastics were feasible to be applied to primary school students. Based on the effectiveness test against 28 models to 10 elementary school students, the pre-test average score was 34.30 while the post-test average score was 69.90 with a difference of 35.6. It can be concluded from these data that the creative exercise learning model treatment for elementary school students' locomotor movement has increased so that this model is considered effective, with field trials and discussion of research results it can be concluded that, 1). The learning model of creative gymnastics for basic locomotor movements of elementary school students can be applied. 2 ). With the creative gymnastics learning model created, it can effectively improve elementary school students' locomotor movement.

\section{Acknowledgments}

No external financial support was received for this study. The authors would like to thank all the volunteers who participated in this study for their participation in assisting with data collection.

\section{REFERENCES}

[1] UU No 3 Tahun 2005, "Undang-Undang Republik Indonesia Nomor 3 Tahun 2005 Tentang Sistem Keolahragaan Nasional Dengan," Pres. RI, vol. 1, no. 1, pp. 1-53, 2005.

[2] J. E. Rink, "Teaching Physical Education For Learning," Res. Teach. Phys. Educ., 2006, doi: 10.1021/am504163r.

[3] D. Sugden and H. Wright, "Physical education," in Enabling Access: Effective Teaching and Learning for Pupils with Learning Difficulties, 2014.

[4] Nur Alyaa Athirah Roslan , Borhannudin Abdullah, "Differences in the Level of Children Gross Motor Skills Development in Silat, Taekwondo and Karate in Malaysia," International Journal of Human Movement and Sports Sciences, Vol. 8, No. 2, pp. 57 - 62, 2020. DOI: 10.13189/saj.2020.080202.

[5] A. Hidayat, "PENINGKATAN AKTIVITAS GERAK LOKOMOTOR, NONLOKOMOTOR DAN MANIPULATIF MENGGUNAKAN MODEL PERMAINAN PADA SISWA SEKOLAH DASAR," $J$. Pendidik. Jasm. DAN OLAHRAGA, 2017, doi: 10.17509/jpjo.v2i2.8175.

[6] L. García Murillo, S. Cortese, D. Anderson, A. Di Martino, and F. X. Castellanos, "Locomotor activity measures in the diagnosis of attention deficit hyperactivity disorder: Meta-analyses and new findings," J. Neurosci. Methods, 2015, doi: 10.1016/j.jneumeth.2015.03.001.

[7] A. E. Staiano and S. L. Calvert, "Exergames for Physical Education Courses: Physical, Social, and Cognitive Benefits," Child Dev. Perspect., 2011, doi: 10.1111/j.1750-8606.2011.00162.x.

[8] M. B. Carvalho et al., "An activity theory-based model for serious games analysis and conceptual design," Comput. Educ., 2015, doi: 10.1016/j.compedu.2015.03.023.

[9] M. D. Gall, J. P. Gall, and W. R. Borg, "Educational Research: An Introduction, 8th Edition," Educ. An Introd., 2006.

[10] Sugiyono, "Metode Penelitian dan Pengembangan (Research and Development/R\&D)," Bandung Alf., 2016, doi: 10.1016/j.drudis.2010.11.005.

[11] Sugiyono, "Metode Penelitian Pendidikan pendekatan Kuantitatif, Kualitatif dan R\&D.," in METODE PENELITIAN ILMIAH, 2014.

[12] T. Araki et al., "Gymnastic formation-related injury to children in physical education," J. Nippon Med. Sch., 2016, doi: $10.1272 /$ jnms. 82.295 .

[13] R. Bailey, Teaching Physical Education. 2013.

[14] C. Kontra, D. J. Lyons, S. M. Fischer, and S. L. Beilock, "Physical Experience Enhances Science Learning," Psychol. Sci., 2015, doi: 10.1177/0956797615569355. 